\title{
The Madeiran laurel forest endemic Goodyera macrophylla (Orchidaceae) is related to American orchids
}

\author{
Mike THIV $^{1^{*}}$, Manuela GOUVEIA ${ }^{2}$, Miguel MENEZES DE SEQUEIRA ${ }^{3}$ \\ ${ }^{1}$ State Museum of Natural History Stuttgart, Rosenstein 1, 70191 Stuttgart, Germany \\ ${ }^{2,3}$ Madeira Botanical Group (GBM), Faculty of Life Sciences, University of Madeira, \\ Campus da Penteada, 9020-105, Funchal, Portugal \\ ${ }^{*}$ Correspondence: mike.thiv@smns-bw.de \\ ${ }^{1} \mathrm{http}: / /$ orcid.org/0000-0002-5670-4109, ${ }^{2}$ https://orcid.org/0000-0001-5758-2230, \\ ${ }^{3}$ https://orcid.org/0000-0001-9728-465X
}

\begin{abstract}
Macaronesian laurel forests harbour many herbs and laurophyllous trees with Mediterranean/European or Macaronesian affinities. Traditionally, the origin of these taxa has been explained by the relict hypothesis interpreting these taxa as relics of formerly widespread laurel forests in the European continent and the Mediterranean. We analysed the phylogenetic relationships of the Madeiran laurel forest endemic Goodyera macrophylla (Orchidaceae) using sequences from the nuclear ribosomal DNA Internal Transcribed Spacers (ITS) and plastid DNA regions. The results were incongruent, either the two Central American G. brachyceras and G. striata (ITS) or the North American G. oblongifolia (plastid DNA) were sister group to G. macrophylla. Nonetheless, biogeographic analyses indicated an American origin of this nemoral laurel forest plant in the two data sets. Molecular clock analyses suggest a colonisation of Madeira in the span of the upper Miocene/lower Pliocene to the Pleistocene. Although the relict hypothesis cannot be ruled out by our data when assuming extinction events on the European and northern African mainland, dispersal from Central or North America to the archipelago of Madeira is a much more likely explanation of the data.
\end{abstract}

Keywords. Biogeography, laurisilva, Macaronesia, orchids, phylogeny.
Resumen. La laurisilva de la Macaronesia alberga muchos árboles laurófilos y hierbas con afinidades mediterráneo/europeas o macaronésicas. El origen de estos taxones se ha explicado por la hipótesis del bosque relicto que interpretaba estos taxones como relictos de bosques de laurel previamente extendidos en Europa y el Mediterráneo. Analizamos las relaciones filogenéticas de Goodyera macrophylla (Orchidaceae), especie endémica de la laurisilva de Madeira, utilizando secuencias del ADN ribosómico (ITS) y de regiones plastidiales. Los resultados fueron incongruentes: las dos especies de Centroamérica, G. brachyceras y G. striata, emergieron como grupo hermano de G. macrophylla en el análisis de ITS, mientras que G. oblongifolia, de Norteamérica, resultó hermana de G. macrophylla en el análisis plastidial. No obstante, los análisis biogeográficos indicaron un origen en norte america para G. macrophylla en los dos conjuntos de datos. Los análisis del reloj molecular sugieren una colonización de Madeira en el lapso del Mioceno superior/Plioceno inferior al Pleistoceno. Aunque nuestros datos no pueden descartar la hipótesis del bosque relicto, cuando se asumen eventos de extinción en Europa y norte de África, la dispersión desde Centro o Norteamérica al archipiélago de Madeira es una explicación mucho más probable de los datos.

Palabras clave. Biogeografia, filogenia, laurisilva, Macaronesia, orquídeas.

How to cite this article: Thiv M., Gouveia M., Menezes de Sequeira M. 2021. The Madeiran laurel forest endemic Goodyera macrophylla (Orchidaceae) is related to American orchids. Anales del Jardín Botánico de Madrid 78: e116. https://doi.org/10.3989/ajbm.2605

Title in Spanish: La especie endémica de la laurisilva de Madeira, Goodyera macrophylla (Orchidaceae), está relacionada con orquídeas americanas.

Associate Editor: Pilar Catalán. Received: 26 May 2021; accepted: 28 October 2021; published online: 20 December 2021.

\section{INTRODUCTION}

Macaronesian laurel forests (MLF) consist of trees with a laurophyll habit and occur in different species compositions on the Canary Islands, Madeira and the Azores (Kondraskov \& al. 2015; Fernández-Palacios \& al. 2018). On the Canary Islands and Madeira, laurel forests retain most of their water supply by NE trade winds (Prada \& al. 2012; Figueira \& al. 2013) and are characterised by evergreen leaves often with thick cuticles. Because of the resemblance of their laurophyllous leaves to Paleogene and Neogene fossils, this vegetation type has traditionally been regarded as an old biome and as a relict remnant of Tertiary (65-2.6 Ma) laurel forests (Hooker 1867; Fernández-Palacios \& al. 2011). Using molecular divergence times, Kondraskov \& al. (2015) found that many key taxa of MLF originated in the Plio-Pleistocene with only a few taxa dating back to the Miocene. This was especially surprising for MLF Lauraceae, namely Laurus novocanariensis Rivas Mart., Lousã, Fern.Prieto, E.Días, J.C.Costa \& C.Aguiar, Ocotea foetens 
(Aiton) Baill., Persea indica (L.) Spreng. and Apollonias barbujana (Cav.) A.Braun, with Pleistocene and Pliocene stem node ages. Close taxonomic links to lauraceous Palaeogene and Neogene fossils attributed to morpho-taxa like Laurus abchasica (Kolakovsky \& Shakryl) Ferguson or Laurophyllum Goeppert (Ferguson 1974; Kvaček \& Teodoridis 2007; Worobiec 2007) were therefore not supported. Based on this evidence Kondraskov \& al. (2015) interpreted MLF to have underwent a high species turn over during time and/or to be relatively newly formed. Other studies analysing Hedera canariensis Willd. (Valcárcel $\&$ al. 2017), Ranunculus cortusifolius Willd. (Williams \& al. 2015), Solanum vespertilio Aiton, S. trisectum Dunal (Echeverría-Londoño \& al. 2020), Gesnouinia arborea (L.f.) Gaudich. (Schüßler \& al. 2019) corroborated evolutionary divergence times for MLF taxa from the Miocene to the Pleistocene. Recently, the finding of fossil fruits of Melanoselinum decipiens (Schrad. \& J.C.Wendl.) Hoffm. from Madeira dating 1.3 Ma (Góis-Marques \& al. 2019) is in accordance with a possible Pleistocene/Pliocene origin of this taxon (Spalik \& al. 2010). As to the spatial patterns of MLF, several geographic regions have been identified as sources (Kondraskov \& al. 2015). Europe served as a major source area, including the Mediterranean. MLF elements also often originated as parts of Macaronesian radiations. Minor biogeographic links with tropical Asia and the Americas were revealed.

An element of MLF with a very restricted area of distribution is the Madeira island endemic Goodyera macrophylla Lowe (Orchidaceae). Described by R. T. Lowe (1831), it is very rare, although locally abundant, growing in forest clearings or ravines in the stink-laurel forest (Clethro arboreae-Ocoteetum foetentis; Costa \& al. 2004) between 300 and 1000 m a.s.l (Press \& Short 1994; Gouveia $\&$ al. in prep.). Its preferences for habitats associated with Ocotea foetens dominated forests was already stated by Lowe (1831): "Hab. gregaria in declivibus sylvarum Maderae humidis. umbrosis. Rariss.". Goodyera macrophylla is a herb with creeping branching rhizomes which forms more or less dense clonal aggregates, with ovate to lanceolate or narrowly elliptic leaves up to $20 \mathrm{~cm}$ long and spikes with 25 to 80 flowers as illustrated in the original water-colour drawings by Lowe kept at Kew (Mesquita \& al. 2020). Rankou (2011) evaluated G. macrophylla as "Critically Endangered" although with a stable population trend and called for more research concerning population size, distribution and trends.

Of the more than 200 described taxa in the genus Goodyera R.Br., about 100 are currently accepted species (Chen $\&$ al. 2009; POWO 2019). Schlechter (1914) originally described two sections of Goodyera, sect. Otosepalum Schltr. with reflexed outer lateral tepals and sect. Eu-Goodyera Schltr. with parallel outer tepals. According to the criteria of this classification, G. macrophylla should belong to sect. Eu-Goodyera. The shape of the outer tepals, however, was found to vary and not to match clades of molecular trees (Hu \& al. 2016). According to $\mathrm{Hu} \&$ al. (2016), Goodyera s.l. is polyphyletic. They recognised four sections of Goodyera: Otosepalum and Goodyera in a different morphological circumscription compared to Schlechter (1914), Reticulum S.W.Chung \& C.H.Ou and a still undescribed section with G. procera Hook. Within the sections Otosepalum, Goodyera and Reticulum several subsections were created based on the topology of the molecular trees. In another study by Chen \& al. (2019), the Goodyera clade consisted of two major groups, the subclade including Goodyera and the subclade including Microchilus C.Presl. Several of these Goodyera s.l. taxa included in the Microchilus subclade have subsequently been excluded from Goodyera and transferred to other genera by Pace (2020). Despite these previous studies, the current understanding of both the taxonomy and of the phylogenetic relationships within the genus is far from being complete. In special, the neotropical taxa are largely underrepresented in molecular genetic analyses and the delimitation of species and infrageneric groups is hampered by convergence of morphological characters (Pace 2020). Goodyera macrophylla has, so far, not been analysed genetically yet and no explicit hypothesis on its systematic affinities has been published.

Goodyera in its wide definition, including the Microchilus subclade, is widely distributed, especially in Asia, but also in northern and Central America, Europe, and it extends to northeast Australia, South Africa, Madagascar and the southwestern Pacific islands (Chen \& al. 2009; Hu \& al. 2016; POWO 2019). Therefore, it seems plausible to assume that G. macrophylla could have originated from one of the subareas of the entire distribution of the genus. Goodyera macrophylla is the only member of Goodyerinae in Macaronesia. Frey \& Pickering (1975) regarded it as a relict species of a former 'Atlantic [island] vegetation' without giving evidence for this statement and no other hypotheses on the biogeographic affinities of G. macrophylla are known. Considering the general patterns observed in the Macaronesian flora, biogeographic relationships to European, American or Asian Goodyera species could occur. The aim of this paper is to provide hypotheses on the phylogenetic relationships and the biogeography of G. macrophylla based on molecular data.

\section{MATERIAL AND METHODS}

\section{Taxon sampling}

DNA sequence data of Goodyera macrophylla was analysed in a phylogenetic framework including Goodyera and other genera of subtribe Goodyerinae (Appendix 1). To test if G. macrophylla is part of other groups be- 
sides Goodyera in its wide circumscription, other genera of Goodyerinae; namely Erythrodes Blume, Kreodanthus Garay and Aspidogyne Garay were also included. Pterostylis R.Br. (Pterostylidinae; sistergroup of Goodyerinae; Givnish \& al. 2015) was used as outgroup. Seventeen DNA sequences of G. macrophylla (Sequeira 9073, 9074, 9114, 10600), G. repens (L.) R.Br. (Thiv 6213) and G. striata Rchb.f. [García 127 (P) MNHN-P-P01019179] were newly generated in the context of this study.

\section{Laboratory protocols and data matrices}

DNA extraction, PCR and sequencing protocols followed Schüßler \& al. (2019). Genetic markers were chosen following $\mathrm{Hu} \&$ al. (2016), Chen \& al. (2019) and Shin \& al. (2002). Accordingly, the nuclear ITS region and the plastid trnL intron, trnL-F spacer and $m a t \mathrm{~K}$ coding region were used for phylogenetic reconstruction (Appendix 1). Primers were obtained from $\mathrm{Hu} \&$ al. (2016) except for $G$. striata, for which we designed new matK primers: matK 225R ACCAAAAATTTCCACAGGTTCGT, matK 225F ACGAACCTGTGGAAATTTTTGGT, matK 578R TCCAGATGGATGGGATGGGG, matK 592F TGCTGGATCAAAGATGTTCCT, matK 1031F GGTCTCAACCTTATAGGATCCATAT, matK 1053R TGGATCCTATAAGGTTGAGACCA, matK 1356R TGAGGATCCGCTGTGATAACG, matK 1345F CGTTATCACAGCGGATCCTCA, matK 1850R ACCGTGCTTGCAGTTTTCAT, matK 1831F ATGAAAACTGCAAGCACGGT. These primers yielded fragments of lengths between ca. 200 and 450 bp using $55^{\circ} \mathrm{C}$ as annealing temperature and $1 \mathrm{~min}$. as elongation time.

For ITS and the plastid DNA markers available sequences of Goodyera species and related taxa (see taxon sampling) were downloaded from GenBank of the National Center for Biotechnology Information (NCBI). Identical and very similar sequences of the same taxon, often grouping together in a clade in a preliminary analysis, and doubtful, possibly incorrect determined sequences were not included. All newly generated sequences were deposited at GenBank, the corresponding accession numbers as well as a detailed list of the analysed samples are given in Appendix 1. DNA sequences were aligned using MAFFT v7.388 (Katoh \& al. 2002) in Geneious 11.1.5.

\section{Data analyses and divergence time estimation}

The ITS data set was $751 \mathrm{bp}$ in length and included 45 species of Goodyera and 13 of Goodyerinae. In the cpDNA matrix 37 species of Goodyera and 8 other representatives of Goodyerinae were included. For non-coding parts of the cpDNA dataset several poly-A/T, very variable, repetitive regions or unique insertions were excluded from the analysis. This concerns the positions $72-96,245-344,412-512$,
535-544, 576-599, 623-650, 721-730, 753-759, 782790, 819-824, 1003-1016, 1069-1077, 1124-1149, 12061224, 1300-1305, 1341-1350, 1374-1388, 1421-1430, 3157-3180, 3301-3310, 3314-3318 of the original dataset (3400 bp) yielding a new matrix with 2929 bp.

Several methods were applied to reconstruct the phylogenetic relationships. Maximum likelihood (ML) trees were calculated using RaxML v8 (Stamatakis 2014). Bayesian inference (BI) trees were generated using MrBayes 3.2.6 (Huelsenbeck \& Ronquist 2001). We used the GTR substitution model with four Gamma categories and the shape being estimated. Four runs of 20,000,000 generations with samples taken every 2,000 generations provided Effective Sample Size values > 200 in TRACER (Rambaut \& Drummond 2007).

To evaluate divergence times for G. macrophylla we used BEAST v2.5 (Drummond $\&$ al. 2012) on the ITS and cpDNA data set. Because these data sets consisted mostly of different species of Goodyera, we used the Yule model and lognormal relaxed clock. The data sets were analysed separately because the position of G. macrophylla differed in the two data sets (see results). Assuming equal probabilities in the 95\% HPD, we applied in our analyses two uniform priors following Givnish \& al. (2015) as secondary calibration points with $15.13-27.13$ my to the most recent common ancestor (mrca) of Pristiglottis (plus other Goodyerinae genera) and all Goodyera species and 12.00-23.07 my to the mrca of Goodyera, Erythrodes and Kreodanthus (Figs. 1, 2). Several analyses have used fossils to date the origin of the orchid family. As example, Ramírez \& al. (2007) dated the origin of the orchid family to the Cretaceous. Using a broad taxon sample, Givnish \& al. (2015) also dated the orchid family to the Cretaceous. They used a total of 17 calibration points for their family dating, among them several monocot fossils which were revised by Iles \& al. (2015). Moreover, they included some calibration points inferred from angiosperm phylogenies and the three fossil orchids from the Miocene belonging to Dendrobium Sw., Earina Lindl. (Conran et al. 2009) and Meliorchis S.R.Ramirez, Gravend., R.B.Singer, C.R.Marshall, N.E.Pierce (Ramírez \& al. 2007). According to Givnish's \& al. (2015) results, within Goodyerinae, the group of Pristiglottis Cretz. \& J.J.Sm and Goodyera is 20.68 my (95\% HPD ca. 15.13-27.13) old and the split between Goodyera, Erythrodes and Kreodanthus is dated to 17.34 my (95\% HPD ca. 12-23.07).

\section{Biogeographic analyses}

For biogeographic analyses, the following areas were coded: A: Eastern and South-Eastern Asia, B: temperate-boreal Asia, C: temperate North America, D: tropical Central America, E: Pacific region, F: Madeira (Macarone- 
sia) and G: Europe. In a second alternative approach, temperate North America (C) and tropical Central America (D) were combined to America.

As input, the dated maximum clade credibility (MCC) consensus trees from the BEAST analyses were used after being reduced to taxa of the Goodyera subclade using Mesquite 3.70 (Maddison \& Maddison 2021). Different biogeographical models, i.e. dispersal-extinction-cladogenesis (DEC), Dispersal-Vicariance Analysis (DIVALI$\mathrm{KE}$ ) and BayArea (BAYAREALIKE) were tested using the BioGeoBEARS R package (Matzke 2013a; Matzke 2013b). The inclusion of founder-event speciation $(+\mathrm{J})$ was also tested for each of these models.

Additionally, Bayesian Binary MCMC (BBM) analyses were conducted using RASP 3.2 (Ronquist \& Huelsenbeck 2003; Yu \& al. 2015). The maximum number of ranges was set to two and nodes supported with posterior probabilities (PP) $<0.90$ were excluded from analyses. The default setting of fixed state frequencies (JC) with equal among-site variation was chosen. For the MCMC settings, the default was used.

\section{RESULTS}

\section{Phylogenetic relationships}

Identical topologies and very similar support values were obtained using MrBayes (not shown), RAxML (not shown) and BEAST (Figs. 1, 2, 3). Accordingly, the overall patterns of phylogenetic reconstructions based on nuclear and plastid DNA largely correspond to the results of Hu \& al. (2016) and Chen \& al. (2019). Within subtribe Goodyerinae, the Goodyera clade with the Goodyera and Microchilus subclades, and the Cheirostylis Blume clade with the Cheirostylis and Ludisia A.Rich. subclades were recovered. In all analyses, G. macrophylla was part of the Goodyera subclade, supporting its attribution to the genus Goodyera. It did not group with Asian or Eurasian taxa, but with two different American taxa.

For the ITS region, the BEAST analyses yielded trees with a mean log-likelihood of -5879.59 with a standard deviation of 8.95 , and lower 95\% HPD of -5897.17, upper 95\% was HPD -5862.56. In this analysis, Goodyera macrophylla was sister to the Central American G. striata/G. brachyceras (A.Rich. \& Galeotti) Garay \& G.A.Romero with a PP of 1.00 (Fig. 1). These three taxa formed a clade together with the North American G. oblongifolia Raf. (PP 1.00). The ITS sequences of all four accessions of G. macrophylla were identical.

The plastid DNA analyses resulted in trees with a mean log-likelihood of -12766.71 with a standard deviation of 7.82 , and lower $95 \%$ HPD of -12781.53 , upper $95 \%$ was
HPD -12750.91. Here, G. macrophylla grouped together with G. oblongifolia (PP 1.00; Fig. 2). Uncorrected pairwise distances among accessions of G. macrophylla varied between 0.0002 and 0.0020 .

The position of the conflicting lineage including Goodyera striata and $G$. brachyceras in different clades was highly supported by PP in the ITS and plastid trees. We still combined the data to follow a total evidence approach. This analysis of combined data using BEAST with the same settings as for the single data sets resulted in mean log-likelihood of -18918.65 with a standard deviation of 10.56 , lower $95 \%$ HPD of -18938.95 an upper $95 \%$ was HPD -18887.11. Here, G. macrophylla was also sister to $G$. oblongifolia, largely corroborating the results of the plastid DNA analyses (Fig. 3).

\section{Divergence time estimation}

In the ITS data set the mrca of Goodyera-Erythrodes-Kreodanthus was dated to 16.75 my (mean), 16.46 my (median), 12.04-21.84 my (95\% HPD), the split between Pristiglottis and Goodyera to 19.25 my (mean), 18.71 my (median), 15.13-25.02 my (95\% HPD), the mrca of G. macrophylla and G. oblongifolia to 6.09 my (mean), $5.88 \mathrm{my}$ (median), 2.93-9.89 my (95\% HPD) and the split between G. macrophylla and G. striata/G. brachyceras to $4.33 \mathrm{my}$ (mean), 4.13 my (median), 1.61-7.33 my (95\% HPD). The crown node of G. macrophylla is 0.7 my (mean), 0.58 my (median), 0.04-1.7 my (95\% HPD) (Fig. 1).

The divergence time calculations yielded the following ages for the plastid DNA: the mrca of Goodyera-Erythrodes-Kreodanthus 16.54 my (mean), 16.05 my (median), 12.17-21.79 my (95\% HPD), the mrca of Pristiglottis-Goodyera 19.24 my (mean), 18.55 my (median), 15.13-25.04 my (95\% HPD), the split between G. macrophylla and G. oblongifolia 6.65 my (mean), 6.44 my (median), 2.80-10.73 my (95\% HPD), the crown node of $G$. macrophylla 0.86 my (mean), 0.79 my (median), 0.18-1.85 my (95\% HPD) (Fig. 2).

The results of the combined data set yielded the following ages: for Goodyera macrophylla and G. oblongifolia 7.46 my (mean), 7.22 my (median), 3.26-12.36 my (95\% HPD), the crown node of G. macrophylla 0.56 my (mean), 0.79 my (median), 0.11-1.16 my (95\% HPD) (Fig. 3).

\section{Biogeographic analyses with ITS data}

According to the AICc criterion, DEC $+\mathrm{J}$ was the most likely model for all tested data sets. To infer the origin of G. macrophylla, the ancestral areas for the node of G. macrophylla and G. striata/G. brachyceras were reconstructed. $\mathrm{DEC}+\mathrm{J}$ analyses yielded Madeira with a probability of 0.5 as ancestral area and Central America with 0.5 when coding 


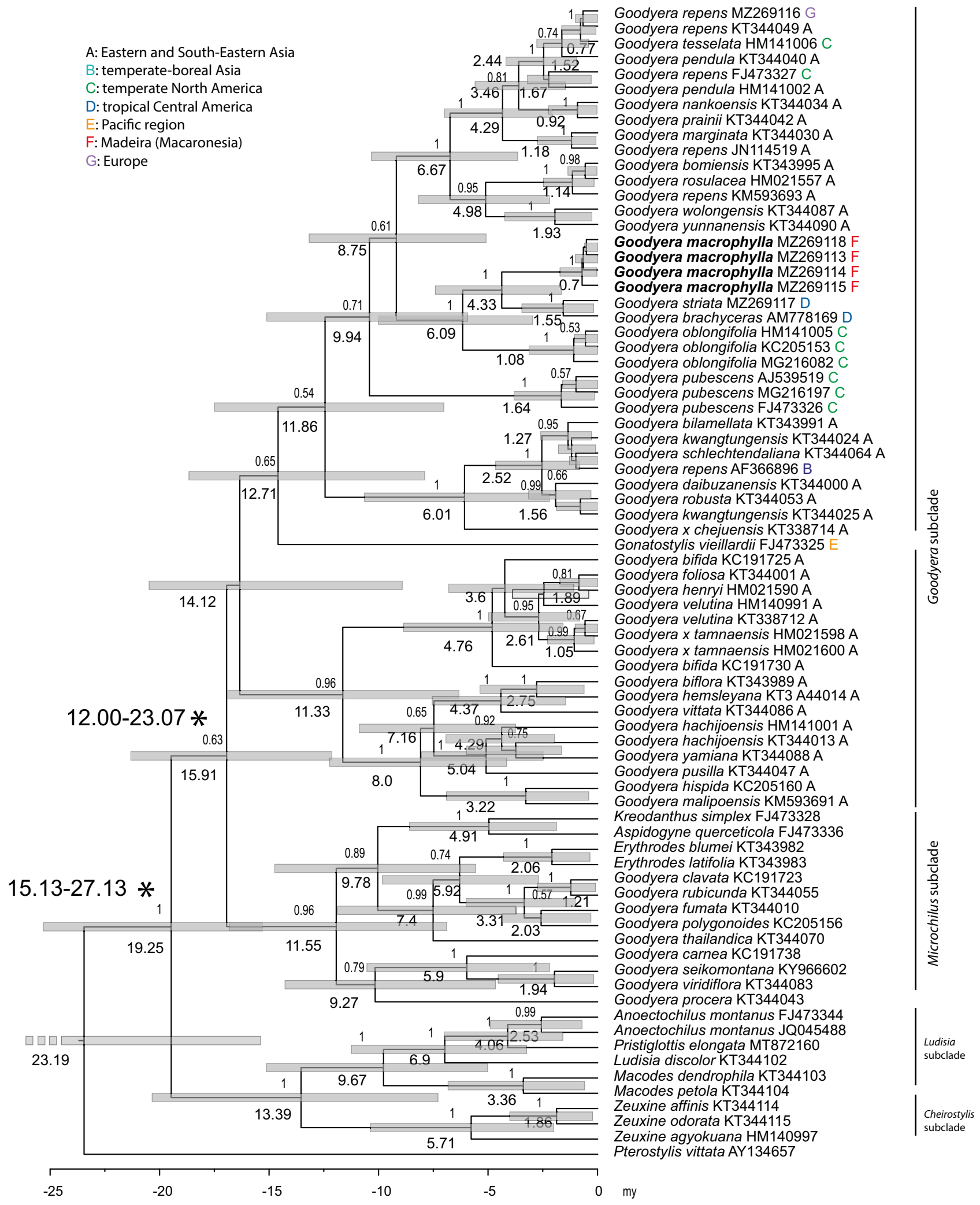

Fig. 1. Phylogenetic Maximum Clade Credibility (MCC) tree of the BEAST analyses of Goodyera and related taxa based on nuclear ribosomal ITS. Numbers at the branches are posterior probabilities. Genbank accession numbers are given behind the taxon names. Capital letters behind Genbank accession numbers of the Goodyera subclade indicate coded areas of distribution. Bars indicate $95 \%$ HPD of age estimations. Mean ages are shown below branches for most of the clades. Calibration points with used dates are given before asterisks (see text). 


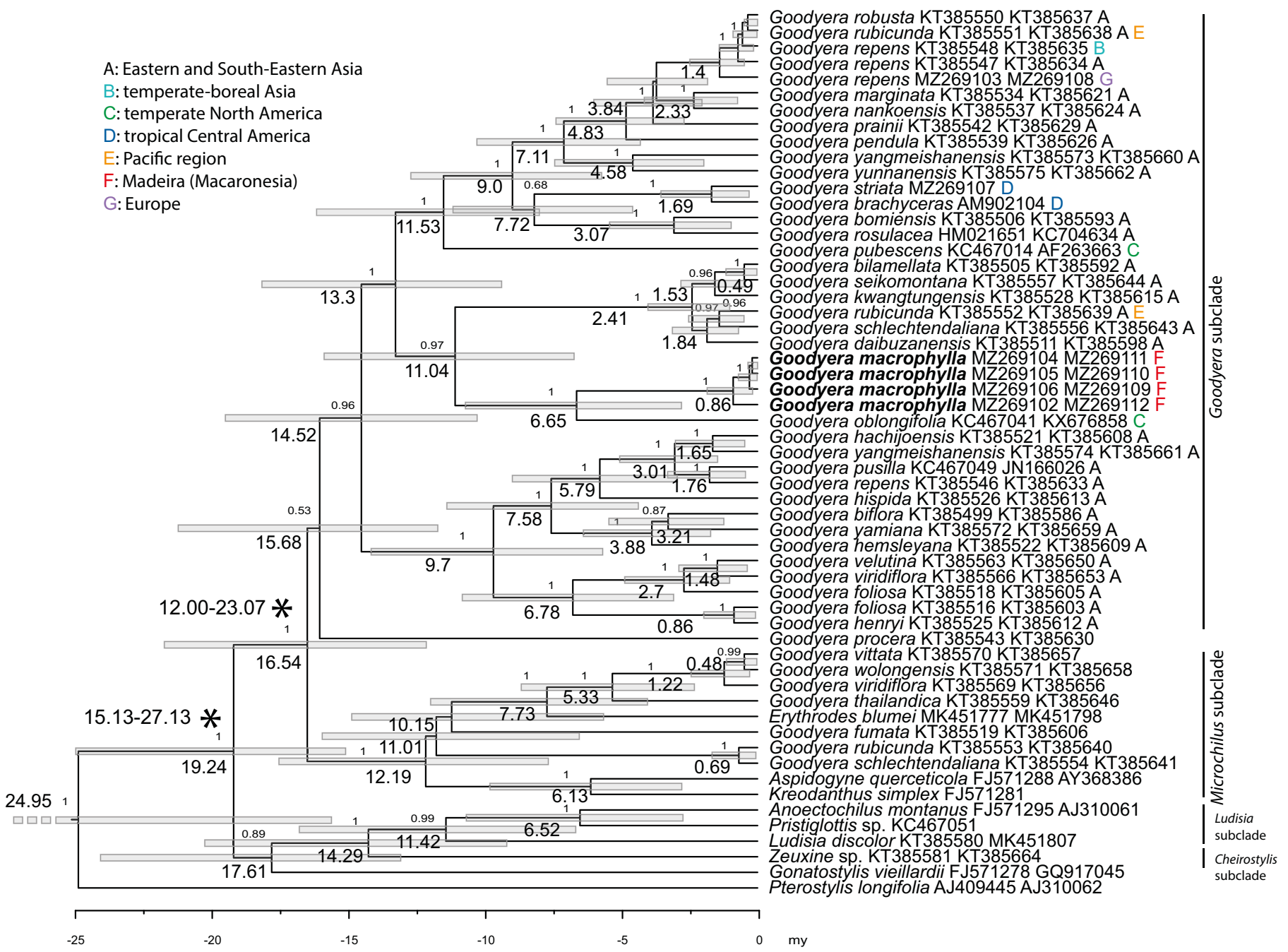

Fig. 2. Phylogenetic MCC tree of the BEAST analyses of Goodyera and related taxa based on plastid DNA (trnL intron, the $t r n L-F$ spacer and $m a t K)$. Numbers at the branches are posterior probabilities. Genbank accession numbers are given behind the taxon names. Capital letters behind Genbank accession numbers of the Goodyera subclade indicate coded areas of distribution. Bars indicate 95\% HPD of age estimations. Mean ages are shown below branches for most of the clades. Calibration points with used dates are given before asterisks (see text).

distinguished between Central and North America (Fig. 4). When only coding America, this region received a probability of 0.98 for this node. BBM analyses resulted in Central America (0.44), Madeira (0.35), North America (0.11) as ancestral areas. Alternatively, when coding only America, this continent (America, 0.93) and Madeira-America (0.07) were revealed as ancestral areas (Fig. 5).

\section{Biogeographic analyses with the plastid data}

For the node of Goodyera macrophylla and G. oblongifolia, North America had a probability of 0.54 and Madeira of 0.35 as ancestral area using DEC $+\mathrm{J}$ analyses. When coding America, America and Madeira had slightly higher values of 0.64 and 0.36 , respectively (Fig. 6). BBM analyses yielded east/south East Asia (0.40), North America (0.29) and Madeira (0.21) for this node (Fig. 7).

\section{DISCUSSION}

\section{Phylogenetic relationships}

The position of Goodyera macrophylla varied in phylogenetic analyses based on ITS and cpDNA data. While the Madeiran endemic is sister to Central American G. brachyceras and G. striata with North American G. oblongifolia being sister to this clade in the ITS analysis, it appears as sister group to $G$. oblongifolia in the cpDNA trees. These phylogenetic relationships are supported by high PP values. Incongruence between the plastid and nuclear datasets was already observed by $\mathrm{Hu} \&$ al. (2016). Possible explanations for this include (ancient) events of hybridisation, chloroplast capture or concerted evolution. One of these mechanisms may also account for the case of G. macrophylla, but further evidence like chromosome numbers or ploidy 


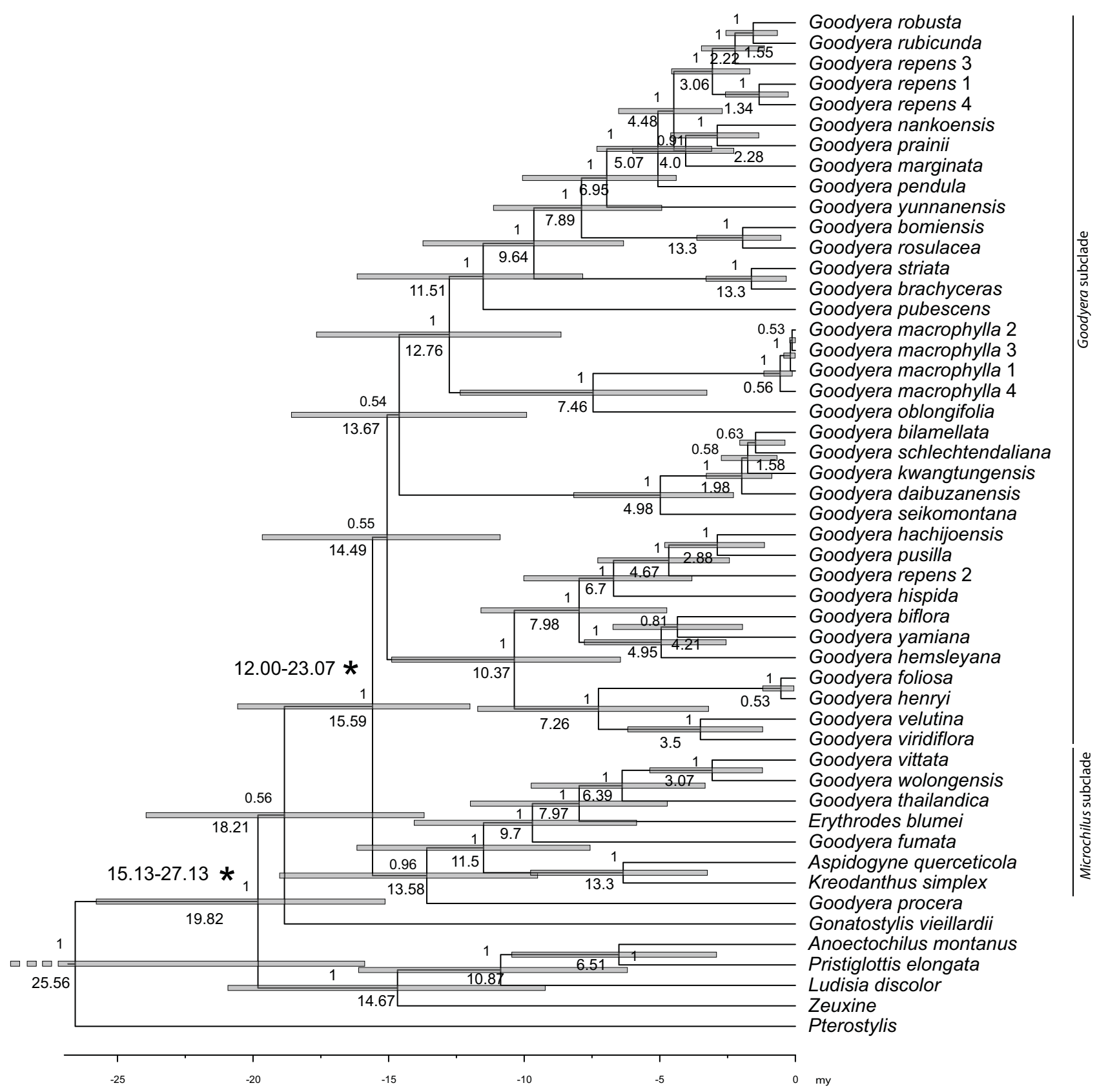

Fig. 3. Phylogenetic consensus tree of the BEAST analyses of Goodyera and related taxa based on combined ITS and plastid DNA ( $\operatorname{trn} L$ intron, the trnL-F spacer and $m a t \mathrm{~K}$ ). Numbers at the branches are posterior probabilities. Bars indicate $95 \%$ HPD of age estimations. Mean ages are shown below branches. Calibration points with used dates are given before asterisks (see text). Numbers behind taxon names refer to superindices in Appendix 1.

levels is not available. A discussion about the phylogenetic pattern of Goodyera is outside of the scope of this study which focuses on G. macrophylla. Despite the incongruence, G. macrophylla always appears as sister to an American group. Goodyera macrophylla shares rather oblong leaves with G. striata and G. brachyceras which are sometimes regarded as synonyms (Garay \& Romero-González 1998; POWO 2019), and G. oblongifolia. Based on the present evidence, we exclude a close relationship of the Madeiran species to Asian or central European taxa, in special to $G$. repens and hypothesise that it is part of a Central or North American clade.

The species-rich genus Goodyera is far from being sufficiently represented in phylogenetic analyses (Pace 2020). Although, all North American species are included in this study, several of the Central American species have not been sequenced for phylogenetic analysis yet and it 


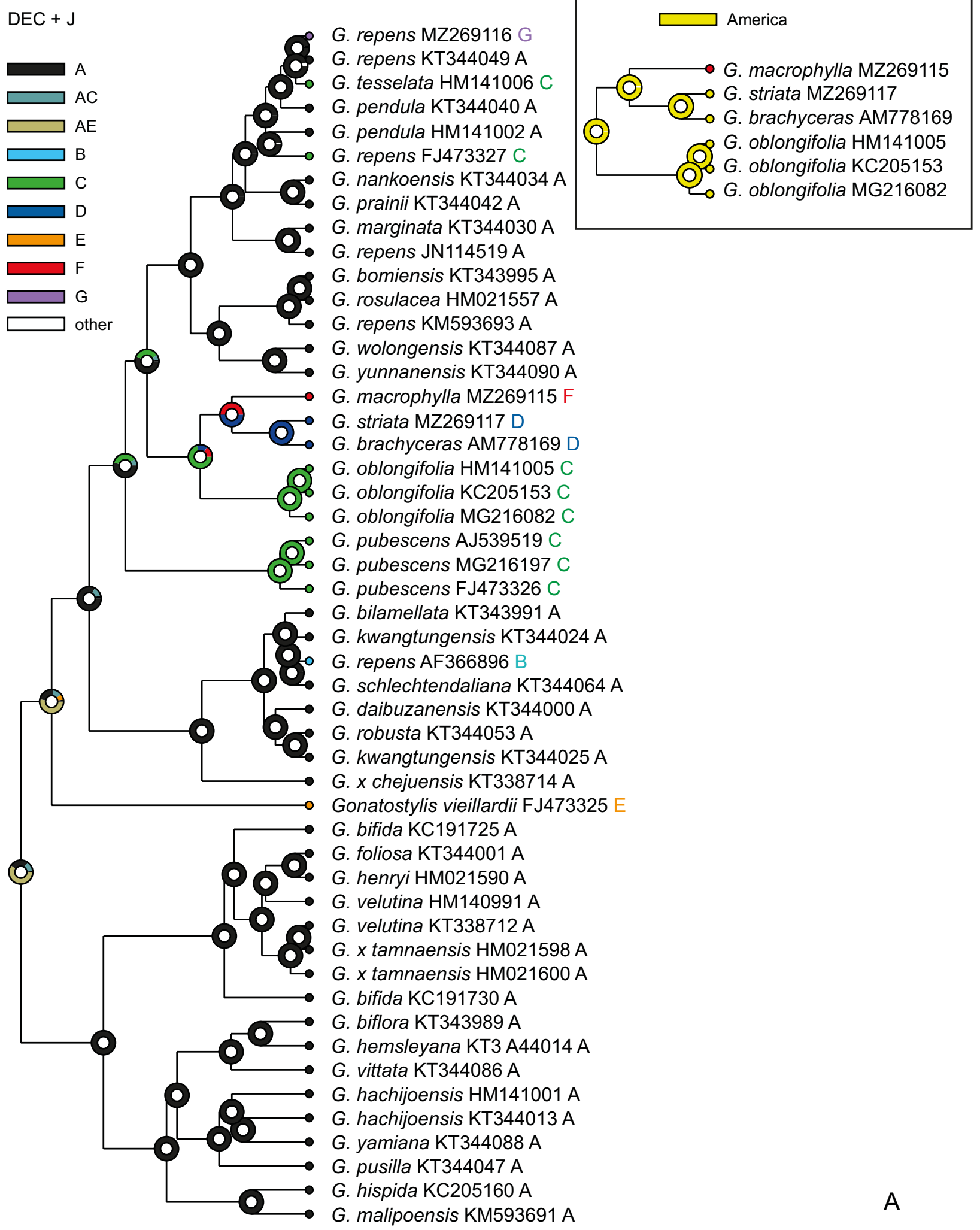

Fig. 4. Ancestral range reconstruction of Goodyera macrophylla and the Goodyera subclade based on the ITS MCC tree and the best fit DEC $+\mathrm{J}$ model using BioGeoBears. Single and compound areas are indicated in the chart: a, coded areas refer to Figure 1; b, reconstruction for G. macrophylla and closest relatives when America was coded as a single area. 

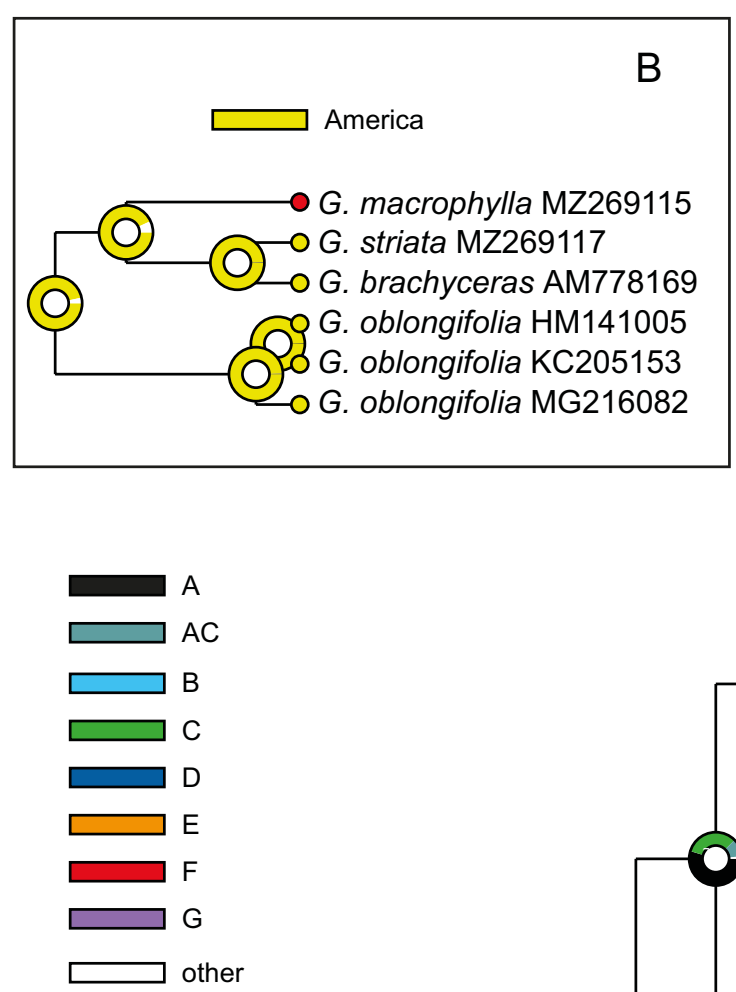

A
BBM

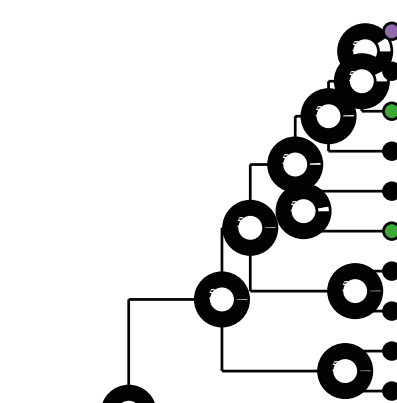

G. repens MZ269116 G

G. repens KT344049 A

G. tesselata HM141006 C

G. pendula KT344040 A

G. pendula HM141002 A

G. repens FJ473327 C

G. nankoensis KT344034 A

G. prainii KT344042 A

G. marginata KT344030 A

G. repens JN114519 A

G. bomiensis KT343995 A

G. rosulacea HM021557 A

G. repens KM593693 A

G. wolongensis KT344087 A

G. yunnanensis KT344090 A

G. macrophylla MZ269115 F

G. striata MZ269117 D

G. brachyceras AM778169 D

G. oblongifolia HM141005 C

G. oblongifolia KC205153 C

G. oblongifolia MG216082 C

G. pubescens AJ539519 C

G. pubescens MG216197 C

G. pubescens FJ473326 C

G. bilamellata KT343991 A

G. kwangtungensis KT344024 A

G. repens AF366896 B

G. schlechtendaliana KT344064 A

G. daibuzanensis KT344000 A

G. robusta KT344053 A

G. kwangtungensis KT344025 A

G. $x$ chejuensis KT338714 A

Gonatostylis vieillardii FJ473325

G. bifida KC191725 A

G. foliosa KT344001 A

G. henryi HM021590 A

G. velutina HM140991 A

G. velutina KT338712 A

G. $x$ tamnaensis HM021598 A

G. $x$ tamnaensis HM021600 A

G. bifida KC191730 A

G. biflora KT343989 A

G. hemsleyana KT3 A44014 A

G. vittata KT344086 A

G. hachijoensis HM141001 A

G. hachijoensis KT344013 A

G. yamiana KT344088 A

G. pusilla KT344047 A

G. hispida KC205160 A

G. malipoensis KM593691 A

Fig. 5. Ancestral range reconstruction of Goodyera macrophylla and other Goodyera species based on Bayesian Binary MCMC (BBM) analyses of the ITS data conducted with RASP 3.2. Single and compound areas are indicated in the chart: a, coded areas refer to Figure 1; b, reconstruction for G. macrophylla and closest relatives when America was coded as a single area (colours refer to A, except for America). 


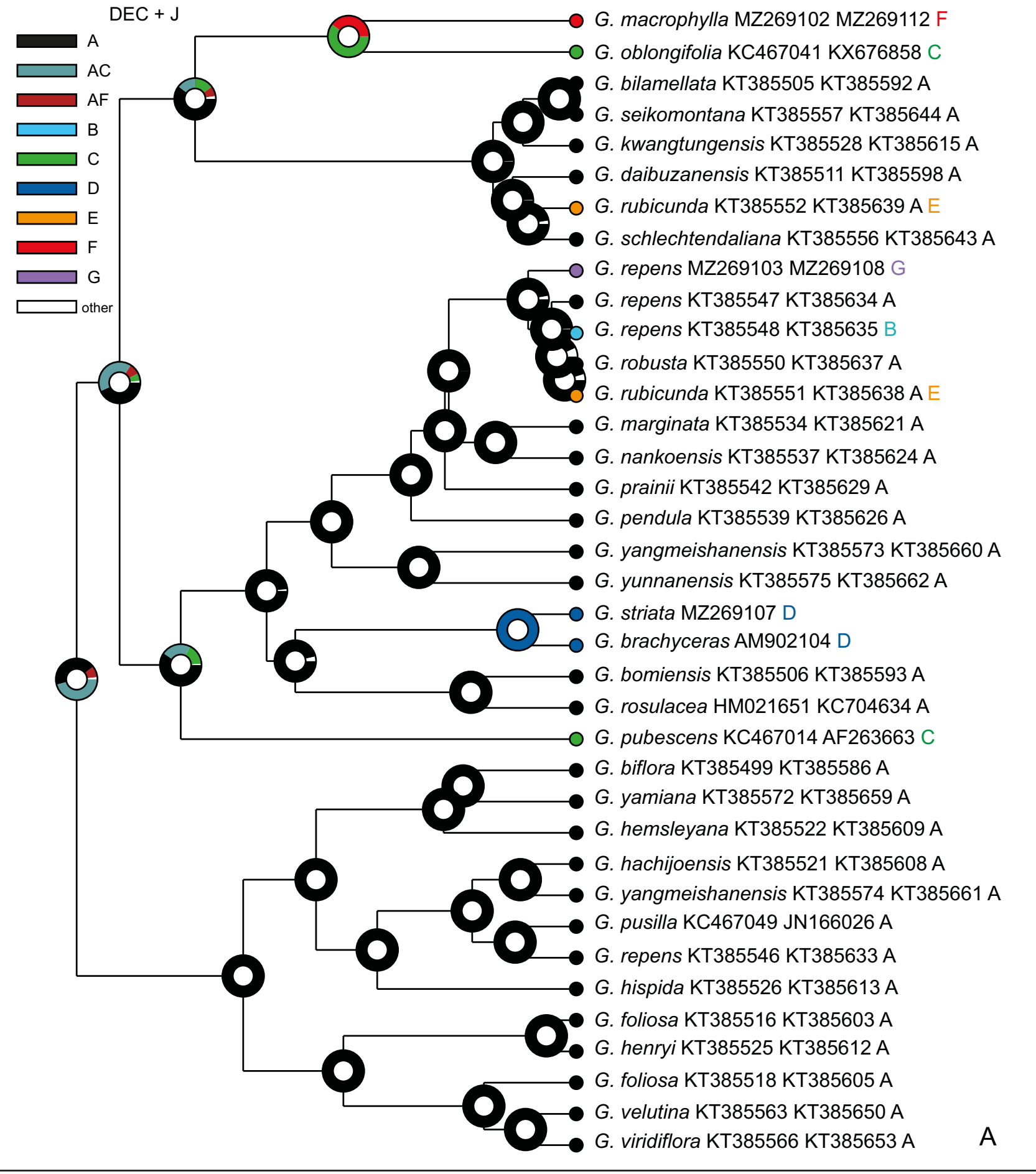

America

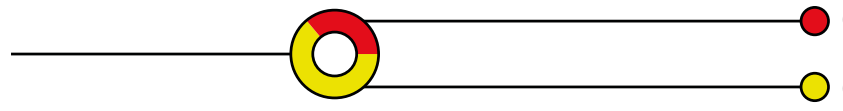

G. macrophylla MZ269102 MZ269112 F

G. oblongifolia KC467041 KX676858 America

Fig. 6. Ancestral range reconstruction of Goodyera macrophylla and the Goodyera subclade based on the plastid DNA MCC tree and the best fit DEC $+\mathrm{J}$ model using BioGeoBears. Single and compound areas are indicated in the chart: a, coded areas refer to Figure 2; b, reconstruction for G. macrophylla and its sister group when America was coded as a single area. 


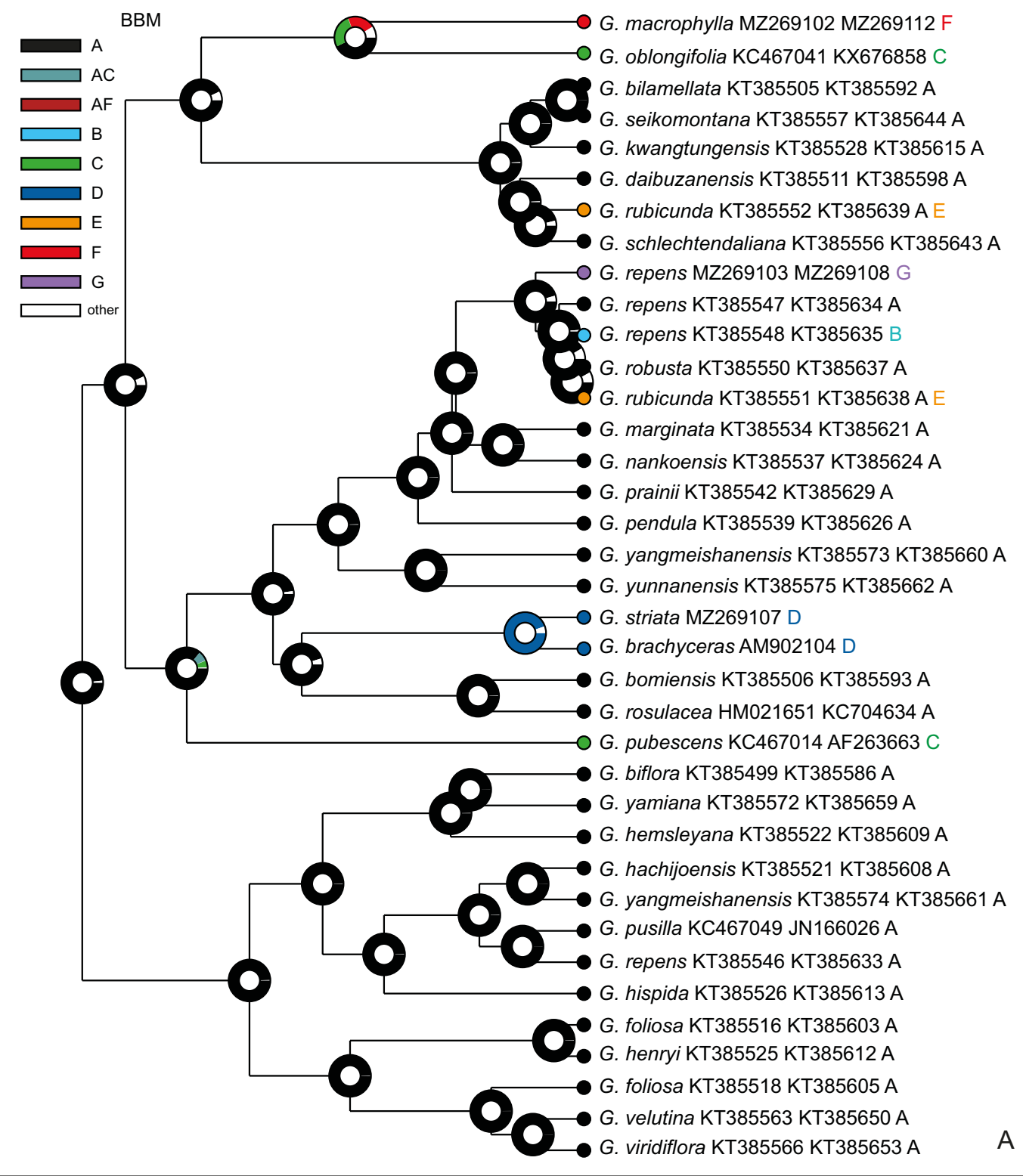

Fig. 7. Ancestral range reconstruction of Goodyera macrophylla and other Goodyera species based on Bayesian Binary MCMC (BBM) analyses of the plastid DNA data conducted with RASP 3.2. Single and compound areas are indicated in the chart: a, coded areas refer to Figure 2; $\mathbf{b}$, reconstruction for $G$. macrophylla and its sister group when America was coded as a single area (colours refer to A, except for America).

appears relatively likely that they may form at least partly geographically defined clades. Therefore, we cannot rule out that G. macrophylla is closest related to other Meso-American Goodyera species which were not included in our analysis. Among such taxa accepted by POWO (2019) are G. bradeorum Schltr., G. corniculata (Rchb.f.) Ackerman, G. dolabripetala (Ames) Schltr., G. erosa (Ames \&
C.Schweinf.) Ames, F.T.Hubb. \& C.Schweinf., G. fimbrilabia Ormerod, G. hispaniolae Dod, G. major Ames \& Correll, G. micrantha Schltr., G. modesta Schltr., G. ovatilabia Schltr., G. polyphylla Ormerod, G. purpusii Ormerod, G. turialbae Schltr., G. venusta Schltr., G. zacuapanensis Ormerod. This supports Pace's (2020) view that more phylogenetic work on Goodyera is needed. 


\section{Geographic origin}

A close putative phylogenetic relationship of Goodyera macrophylla to American taxa prompts the question on the origin of this Macaronesian laurel forest nemoral element. Most biogeographic analyses yielded North and or Central America as the source area for G. macrophylla. Given the fact that Madeira is of volcanic origin (Geldmacher \& al. 2006) which requires biotic dispersal from outside of the island at a certain point, colonisation from America to Madeira seems plausible in this case. The small, light seeds of Orchidaceae are easily dispersed by wind. Another orchid illustrating the dispersal ability from North America to Atlantic islands is Spiranthes romanzoffiana Cham. which is found in large parts of North America and in Ireland and Great Britain. Dueck \& al. (2014) discussed wind transport and exozoochory by birds as possible vectors explaining this disjunction. References to biogeographical links from America to Macaronesia are rather scarce. Kondraskov \& al. (2015) found only $6 \%$ of laurel forest elements originating from America. Accordingly, G. macrophylla is in line with other taxa showing Macaronesian-American links like Persea indica, Arbutus canariensis Veill. ex Duhamel (Hileman \& al. 2001; Kondraskov \& al. 2015), Clethra arborea Aiton (Fior \& al. 2003) and possibly Pericallis D. Don. (Panero \& al. 1999; but see Swenson \& Manns 2003). Among other orchids occurring on Madeira are the two endemics, Orchis mascula subsp. scopulorum (Summerh.) H.Sund. ex H.Kretzschmar, Eccarius \& H.Dietr. and Dactylorhiza foliosa (Rchb.f.) Soó and the Mediterranean Neotinea maculata (Desf.) Stearn as well as Gennaria diphylla (Link) Parl. (Press \& Short 1994). Phylogenetic analyses indicate affinities with the European/ Mediterranean flora for the first three of these four Madeiran species (the relationships of Gennaria diphylla are not resolved; Bateman et al. 2003), stressing the exceptional biogeographic pattern of Goodyera macrophylla.

\section{Estimated age}

Our divergence time estimations yielded ca. 4 (1.3-7.2) my and 6.3 (2.45-10.63) my for the stem node of Goodyera macrophylla, respectively in the ITS and cpDNA datasets. This discrepancy is likely due to the different phylogenetic topologies which are discussed above. Still, these molecular clock calculations suggest that G. macrophylla earliest originated in the Upper Pliocene or Lower Miocene.

These dates could still be adjusted if any of the so far unsampled Goodyera species would appear as the closest relative of the Madeiran endemic. These cases could lead to a younger stem node age of G. macrophylla. Other MLF elements of presumably similar stem node age are Heberdenia excelsa (Aiton) DC., Picconia excelsa (Aiton) DC., Bystropogon L'Hér. sect. Canariense La-Serna, and the Pericallis hansenii (G.Kunkel) Sunding clade (Kondraskov \& al. 2015; Schüßler 2020). Still, the majority of investigated MLF plants is younger than Goodyera. Using a different interpretation of divergence times, e.g., favouring crown nodes ages as indicator for colonisation times (García-Verdugo $\&$ al. 2019), a much younger colonisation in the Pleistocene indicated by the crown node of G. macrophylla (0.04-1.85 my) would indeed be possible. In the end, stem and crown node ages represent the temporal span in which island colonisation happened. In our case this includes the Upper Miocene, Pliocene and Pleistocene. Fossils of the São Jorge flora on Madeira (Góis-Marques \& al. 2017) show that suitable conditions for laurel forests, in special the stink-laurel temperate forest association sensu Capelo \& al. (2005) existed at least since $1.8 \mathrm{my}$ ago. The variation of infraspecific cpDNA is in line with crown node ages, suggesting that $G$. macrophylla diversified on Madeira since the Pleistocene. This is also of interest for conservation purposes. Still, the level of clonality within populations is still unknown and under current investigation (Gouveia \& al. in prep.).

Considering its sister group relationship to American taxa, it seems obvious that the Madeiran species does not fulfil the criteria for the relict hypothesis of Macaronesian laurel forests (Kondraskov \& al. 2015). Originally, this hypothesis relates to Central European and Mediterranean laurel forests, which went extinct at the latest by the end of the Pliocene (Kondraskov \& al. 2015). A sister group relationship to American taxa contradicts this assumption. Theoretically, the relict hypothesis could only be upheld, if extinction of more closely related continental European Goodyera taxa is assumed. However, since there is no evidence for this, we refrain from such explanation. Frey \& Pickering's (1975) hypothesis that G. macrophylla is a relict species of a former Atlantic vegetation, is not supported by our data. Under this scenario, closest relatives of $G$. macrophylla should still be present in laurel forests of the Canary Islands or the Azores, which is not the case. Only the assumption of extinction events in the Atlantic archipelagos could then uphold this hypothesis. This is theoretically possible, but in our view rather unlikely. Based on the available data, we hypothesise that $G$. macrophylla colonised the Madeiran laurel forest earliest in the lower Miocene/upper Pliocene from America.

\section{ACKNOWLEDGEMENTS}

We would like to thank Arnoldo Santos-Guerra (La Palma) for his help in the field, Sonja Dumendiak and Anne-Kristin Schilling (all Stuttgart) for lab work and Christina Schüßler (Stuttgart) for assistance in biogeographic analyses. Madeiran plants were collected under permit 01/IFCN/2019-FLO MAD issued by the Instituto das Florestas e Conservação da Natureza, IP-RAM (Madeira, Portugal). We are grateful to Thomas Bamann of the Regierungspräsidium Tübingen (Germany) who granted the permission to collect plant material. We also thank the curators of $\mathrm{P}(\mathrm{MNHN})$ for access to herbarium material. We thank an anonymous reviewer, M. Moura, and Pilar Catalan for precious advice improving the manuscript. 


\section{REFERENCES}

Bateman R.M., Hollingsworth P.M., Preston J., Yi-Bo L., Pridgeon A.M. \& Chase M.W. 2003. Molecular phylogenetics and evolution of Orchidinae and selected Habenariinae (Orchidaceae). Botanical Journal of the Linnean Society 142: 1-40.

Capelo J., de Sequeira M.M., Jardim R., Mesquita S. \& Costa J.C. 2005. The vegetation of Madeira Island (Portugal). A brief overview and excursion guide. Quercetea 7: 95-122.

Chen S.-P., Tian H.-Z., Guan Q.-X., Zhai J.-W., Zhang G.-Q., Chen L.-J., Liu Z.-J., Lan S.-R. \& Li M.-H. 2019. Molecular systematics of Goodyerinae (Cranichideae, Orchidoideae, Orchidaceae) based on multiple nuclear and plastid regions. Molecular Phylogenetics and Evolution 139: 106542.

Chen X., Lang K.-Y., Gale S., Cribb P. \& Ormerod P. 2009. Goodyera. In Zheng-Yi W., Raven P. \& De-Yuan H. (eds.), Flora of China: 45-54. Missouri Botanical Garden Press, Missouri.

Conran J.G., Bannister J.M. \& Lee D.E. 2009. Earliest orchid macrofossils: Early Miocene Dendrobium and Earina (Orchidaceae: Epidendroideae) from New Zealand. American Journal of Botany 96: 466-474.

Costa J.C., Capelo J., Jardim R., de Sequeira M.M., Espírito Santo D., Lousã M., Fontinha S., Aguiar C. \& Rivas-Martinez S. 2004. Catálogo sintaxonómico e florístico das comunidades vegetais da Madeira e do Porto Santo. Quercetea 6: 61-185.

Dueck L.A., Aygoren D. \& Cameron K.M. 2014. A molecular framework for understanding the phylogeny of Spiranthes (Orchidaceae), a cosmopolitan genus with a North American center of diversity. American Journal of Botany 101: 1551-1571.

Drummond A.J., Suchard M.A., Xie D. \& Rambaut A. 2012. Bayesian phylogenetics with BEAUti and the BEAST 1.7. Molecular Biology and Evolution 29: 1969-1973.

Echeverría-Londoño S., Särkinen T., Fenton I.S., Purvis A. \& Knapp S. 2020. Dynamism and context-dependency in diversification of the megadiverse plant genus Solanum (Solanaceae). Journal of Systematics and Evolution 58: 767-782.

Ferguson D.K. 1974. On the taxonomy of recent and fossil species of Laurus (Lauraceae). Botanical Journal of the Linnean Society 68: 51-72.

Fernández-Palacios J.M., de Nascimento L., Otto R., Delgado J.D., García-del-Rey E., Arévalo J.R. \& Whittaker R.J. 2011. A reconstruction of Palaeo-Macaronesia, with particular reference to the long-term biogeography of the Atlantic island laurel forests. Journal of Biogeography 38: 226-246.

Fernández-Palacios J.M., Arévalo J.R, Balguerías E., Barone R., Nascimento L., Delgado J., Elias R., Fernández-Lugo S., J, de Sequeira M.M., Naranjo-Cigala A. \& Otto R. 2018. The Laurisilva. Canaries, Madeira and Azores. Macaronesia Editorial, Santa Cruz de Tenerife.

Figueira C., de Sequeira M.M., Vasconcelos R. \& Prada S. 2013. Cloud water interception in the temperate laurel forest of Madeira Island. Hydrological Sciences Journal 58: 152-161.

Fior S., Karis P.O. \& Anderberg A.A. 2003. Phylogeny, taxonomy, and systematic position of Clethra (Clethraceae, Ericales) with notes on biogeography: evidence from plastid and nuclear DNA sequences. International Journal of Plant Sciences 164: 997-1006.

Frey G. \& Pickering C. 1975. Contribution to the knowledge of the orchids of Madeira and the Azores. Bocagiana 38: 1-20.

Garay L.A. \& Romero-González G.A. 1998. Schedulae Orchidum. Harvard Papers in Botany 3: 53-62.
García-Verdugo C., Caujapé-Castells J. \& Sanmartín I. 2019. Colonization time on island settings: lessons from the Hawaiian and Canary Island floras. Botanical Journal of the Linnean Society 191: 155-163.

Geldmacher J., Hoernle K., Klügel A., Wombacher F. \& Berning B. 2006. Origin and geochemical evolution of the Madeira-Tore Rise (eastern North Atlantic). Journal of Geophysical Research 111: B09206.

Givnish T.J., Spalink D., Ames M., Lyon S.P., Hunter S.J., Zuluaga A., Iles W.J., Clements M.A., Arroyo M.T. \& Leebens-Mack J. 2015. Orchid phylogenomics and multiple drivers of their extraordinary diversification. Proceedings Royal Society of London Series B Biological Sciences 282: 20151553.

Góis-Marques C.A., MadeiraJ. \& de Sequeira M.M. 2017. Inventory and review of the Mio-Pleistocene São Jorge flora (Madeira Island, Portugal): palaeoecological and biogeographical implications. Journal of Systematic Palaeontology 16: 159-177.

Góis-Marques C.A., de Nascimento L., Fernández-Palacios J.M., Madeira J. \& de Sequeira M.M. 2019. Tracing insular woodiness in giant Daucus (s.1.) fruit fossils from the Early Pleistocene of Madeira Island (Portugal). Taxon 68: 1314-1320.

Hileman L.C., Vasey M.C. \& Parker V.T. 2001. Phylogeny and biogeography of the Arbutoideae (Ericaceae): Implications for the Madrean-Tethyan hypothesis. Systematic Botany 26: 131-143.

Hooker J.D. 1867. On insular floras. Gardeners' Chronicle 6-7, 27, 50$51,75-76$.

Hu C., Tian H., Li H., Hu A., Xing F., Bhattacharjee A., Hsu T., Kumar P. \& Chung S. 2016. Phylogenetic analysis of a 'Jewel Orchid' Genus Goodyera (Orchidaceae) based on DNA Sequence Data from Nuclear and Plastid Regions. PloS one 11: e0150366.

Huelsenbeck J.P. \& Ronquist F. 2001. MRBAYES: Bayesian inference of phylogenetic trees. Bioinformatics 17: 754-755.

Iles W.J., Smith S.Y., Gandolfo M.A. \& Graham S.W. 2015. Monocot fossils suitable for molecular dating analyses. Botanical Journal of the Linnean Society 178: 346-374.

Katoh K., Misawa K., Kuma K.I. \& Miyata T. 2002. MAFFT: a novel method for rapid multiple sequence alignment based on fast Fourier transform. Nucleic Acids Research 30: 3059-3066.

Kondraskov P., Schütz N., Schüßler C., de Sequeira M.M., SantosGuerra A., Caujapé-Castells J., Jaén-Molina R., Marrero-Rodríguez Á., Koch M.A., Linder P., Kovar-Eder J. \& Thiv M. 2015. Biogeography of Mediterranean Hotspot Biodiversity: Re-Evaluating the 'Tertiary Relict' Hypothesis of Macaronesian Laurel Forests. PloS one 10: p.e0132091.

Kvaček Z. \& Teodoridis V. 2007. Tertiary macrofloras of the Bohemian Massif: a review with correlations within Boreal and Central Europe. Bulletin of Geosciences 82: 383-408.

Lowe R. 1831. Primitiæ faunæ et floræ Maderæ et Portus Sancti sive, Species quædam novæ vel hactenus minus rite cognitæ animalium et plantarum in his insulis degentium breviter descriptæ. Transactions of the Cambridge Philosophical Society 4: 1-70.

Maddison W. P. \& Maddison D.R. 2021. Mesquite: a modular system for evolutionary analysis. Version 3.70. http://www.mesquiteproject.org.

Matzke N.J. 2013a. BioGeoBEARS: BioGeography with Bayesian (and Likelihood) Evolutionary Analysis in R Scripts. Website: http://CRAN.Rproject.org/package=BioGeoBEARS. [accessed: 5 Oct. 2020].

Matzke N.J. 2013b. Probabilistic historical biogeography: new models for founder-event speciation, imperfect detection, and fossils allow improved accuracy and model-testing. Frontiers of Biogeography 5: 242-248. 
Mesquita S., Castel-Branco C. \& de Sequeira M.M. 2020. Richard Thomas Lowe, an unknown Botanical Illustrator. Revista Scientia Insularum 3: 59-71.

Pace M.C. 2020. A recircumscription of Goodyera (Orchidaceae) including the description of Paorchis gen. nov., and resurrection of Cionisaccus, Eucosia, and Salacistis. Brittonia 72: 257-267.

Panero J.L., Francisco-Ortega J., Jansen R.K. \& Santos-Guerra A. 1999. Molecular evidence for multiple origins of woodiness and a New World biogeographic connection of the Macaronesian Island endemic Pericallis (Asteraceae: Senecioneae). Proceedings of the National Academy of Sciences 96: 13886-13891.

POWO 2019. Plants of the World Online. Website: http://www plantsoftheworldonline.org/. [accessed: 23 Sep. 2020].

Prada S., de Sequeira M.M., Figueira C. \& Vasconcelos R. 2012. Cloud water interception in the high altitude tree heath forest (Erica arborea L.) of Paul da Serra Massif (Madeira, Portugal). Hydrological Processes 26: 202-212.

Press J.R. \& Short M. 1994. Flora of Madeira. HMSO, London.

Rambaut A. \& Drummond A.J. 2007. Tracer v1. 4. Website: https://beast community/tracer [accessed: 15 Mar. 2020]

Ramírez S.R., Gravendeel B., Singer R.B., Marshall C.R. \& Pierce N.E. 2007. Dating the origin of the Orchidaceae from a fossil orchid with its pollinator. Nature 448: 1042-1045.

Rankou H. 2011. Goodyera macrophylla. The IUCN Red List of Threatened Species 2011: e.T162070A5527443. Website: https://dx.doi. org/10.2305/IUCN.UK.2011-2.RLTS.T162070A5527443.en [accessed 23 Sep. 2020].

Ronquist F. \& Huelsenbeck J.P. 2003. MrBayes 3: Bayesian phylogenetic inference under mixed models. Bioinformatics 19: 1572-1574.

Schlechter R. 1914. Die Orchidaceen von Deutsch-Neu-Guinea. Repertorium Specierum Novarum Regni Vegetabilis 1: 47-53.

Schüßler C. 2020. No Tertiary relicts? A biogeographical study on the Macaronesian laurel forest species in Daucus (Apiaceae), Geranium
(Geraniaceae), Gesnouinia (Urticaceae), Phyllis (Rubiaceae), Semele (Asparagaceae) and Visnea (Pentaphylacaceae). Ph.D. dissertation, University of Heidelberg, Heidelberg.

Schüßler C., Bräuchler C., Reyes-Betancort J.A., Koch M.A. \& Thiv M. 2019. Island biogeography of the Macaronesian Gesnouinia and Mediterranean Soleirolia (Parietarieae, Urticaceae) with implications for the evolution of insular woodiness. Taxon 68: 537-556.

Shin K.-S., Shin Y.K., Kim J.-H. \& Tae K.-H. 2002. Phylogeny of the genus Goodyera (Orchidaceae; Cranichideae) in Korea based on nuclear ribosomal DNA ITS region sequences. Journal of Plant Biology 45: 182.

Spalik K., Piwczyński M., Danderson C.A., Kurzyna-Młynik R., Bone T.S. \& Downie S.R. 2010. Amphitropic amphiantarctic disjunctions in Apiaceae subfamily Apioideae. Journal of Biogeography 37: 1977-1994.

Stamatakis A. 2014. RAxML version 8: a tool for phylogenetic analysis and post-analysis of large phylogenies. Bioinformatics 30: 1312-1313.

Swenson U. \& Manns U. 2003. Phylogeny of Pericallis (Asteraceae): a total evidence approach reappraising the double origin of woodiness. Taxon 52: 533-548.

Valcárce V., Guzmán B., Medina N., Vargas P. \& Wen J. 2017. Phylogenetic and paleobotanical evidence for late Miocene diversification of the Tertiary subtropical lineage of ivies (Hedera L., Araliaceae). BMC Evolutionary Biology 17: 1-14.

Williams B.R., Schaefer H., de Sequeira M.M., Reyes-Betancort J.A., Patiño J. \& Carine M.A. 2015. Are there any widespread endemic flowering plant species in Macaronesia? Phylogeography of Ranunculus cortusifolius. American Journal of Botany 102: 1736-1746.

Worobiec G. 2007. Laurus abchasica (Kolakovsky \& Shakryl) Ferguson from the Neogene of the Belchatow Lignite Mine (Central Poland). Acta Palaeobotanica 47: 203-215.

Yu Y., Harris A.J., Blair C. \& He X. 2015. RASP (Reconstruct Ancestral State in Phylogenies): a tool for historical biogeography. Molecular Phylogenetics and Evolution 87: 46-49.

Appendix 1. Genbank accessions of sequences of Goodyera and related lineages included in the phylogenetic analysis. Items are separated by semicolon in this order for each taxon: taxon name; voucher; ITS; $\operatorname{trn} L-F$; and matK Genbank accession/s numbers. Voucher information is only given for the newly generated sequences. Missing data:-. An asterisk indicates sequences used in the combined analysis; a superindex indicates the accession of the taxon in figure 3 (analysis of combined data sets).

Anoectochilus montanus Schltr.; -; FJ473344, JQ045488*; FJ571295*; AJ310061*. Aspidogyne querceticola (Lindl.) Meneguzzo; -; FJ473336*; FJ571288*; AY368386*. Erythrodes blumei (Lindl.) Schltr.;-; KT343982*; MK451777*; MK451798*. Erythrodes latifolia Blume;-; KT343983; -; -. Gonatostylis vieillardii (Rchb.f.) Schltr; -; FJ473325*; FJ571278*; GQ917045*. Goodyera bifida (Blume) Blume; -; KC191725, KC191730; -; -. Goodyera biflora (Lind1.) Hook.f.; -; KT343989*; KT385499 *; KT385586*. Goodyera bilamellata Hayata;-; KT343991*; KT385505*; KT385592*. Goodyera bomiensis K.Y.Lang; -; KT343995*; KT385506*; KT385593*. Goodyera brachyceras (A.Rich. \& Galeotti) Garay \& G.A.Romero; -; AM778169*; -; AM902104*. Goodyera carnea A.Rich.; -; KC191738; -; -. Goodyera clavata N.Pearce \& P.J.Cribb; -; KC191723; -; -. Goodyera daibuzanensis Yamam.; -; KT344000*; KT385511*; KT385598*. Goodyera foliosa (Lindl.) Benth. Ex C.B.Clarke; -; KT344001*; KT385516*, KT385518; KT385603*, KT385605 . Goodyera fumata Thwaites; -; KT344010*; KT385519*; KT385606*. Goodyera hachijoensis Yatabe; -; HM141001, KT344013*; KT385521*; KT385608*. Goodyera hemsleyana King \& Pantl.; -; KT344014*; KT385522*; KT385609*. Goodyera henryi Rolfe; -; HM021590*; KT385525*; KT385612*. Goodyera hispida Lindl.; -; KC205160*; KT385526*; KT385613*. Goodyera kwangtungensis C.L.Tso;-; KT344024, KT344025*; KT385528*; KT385615*. Goodyera macrophylla Lowe; Portugal, Madeira, Sequeira 9073 (UMAD); MZ269118*1; MZ269106*1; MZ269109*1. Goodyera macrophylla Lowe; Portugal, Madeira, Sequeira 9074 (UMAD); MZ269113*2; MZ269104*2; MZ269111*2. Goodyera macrophylla Lowe; Portugal, Madeira, Sequeira 9114 (UMAD); MZ269114*3; MZ269105*3; MZ269110*3. Goodyera macrophylla Lowe; Portugal, Madeira, Sequeira 10600 (UMAD); MZ269115*4; MZ269102*4; MZ269112*4. Goodyera malipoensis Q.X.Guan \& S.P.Chen; -; KM593691; -; -. Goodyera marginata Lind1.; -; KT344030*; KT385534*; KT385621*. Goodyera nankoensis Fukuy.; -; KT344034*; KT385537*; KT385624*. Goodyera oblongifolia Raf.; -; HM141005, KC205153*, MG216082; KC467041*; KX676858*. Goodyera pendula Maxim.; -; HM141002, KT344040*; KT385539*; KT385626*. Goodyera polygonoides F.Muell.; -; KC205156; -; -. Goodyera prainii Hook.f.; -; KT344042*; KT385542*; KT385629*. Goodyera procera (Ker Gawl.) Hook.; -; KT344043*; KT385543*; KT385630*. Goodyera pubescens (Willd.) R.Br.; -; AJ539519*, FJ473326, MG216197; KC467014*; AF263663*. Goodyera pusilla Blume; -; KT344047*; KC467049*; JN166026*. Goodyera repens (L.) R.Br.; 
Germany, Baden-Württemberg, Eglingen, leg. Thiv 6213 (STU); MZ269116*1; MZ269103*1; MZ269108*1. Goodyera repens (L.) R.Br.; -; AF366896, FJ473327, JN114519*2, KM593693*3, KT344049*4; KT385546*2, KT385547*3, KT385548*4; KT385633*2, KT385634*3, KT385635*4. Goodyera robusta Hook.f.; -; KT344053; KT385550; KT385637. Goodyera rosulacea Y.N.Lee; -; HM021557; HM021651; KC704634. Goodyera rubicunda (Blume) Lindl.; -; KT344055*; KT385551*, KT385552, KT385553; KT385638*, KT385639, KT385640. Goodyera schlechtendaliana Rchb.f.; -; KT344064*; KT385554*, KT385556; KT385641*, KT385643. Goodyera seikoomontana Yamam.; -; KY966602*; KT385557*; KT385644*. Goodyera striata Rchb.f.; Mexico, leg. Carrada García 127 (P) MNHN-P-P01019179; MZ269117*; -; MZ269107*. Goodyera tesselata Lodd.; -; HM141006; -; -. Goodyera thailandica Seidenf.; -; KT344070*; KT385559*; KT385646*. Goodyera velutina Maxim. ex Regel; -; HM140991, KT338712*; KT385563*; KT385650*. Goodyera viridiflora (Blume) Blume; -; KT344083*; KT385566*, KT385569; KT385653*, KT385656. Goodyera vittata (Lindl.) Benth. ex Hook.f.; -; KT344086*; KT385570*; KT385657*. Goodyera wolongensis K.Y.Lang; -; KT344087*; KT385571*; KT385658*. Goodyera yamiana Fukuy.; -; KT344088*; KT385572*; KT385659*. Goodyera yunnanensis Schltr.; -; KT344090*; KT385575*; KT385662*. Goodyera $x$ chejuensis S.Kim ex C.S.Lee \& N.S.Lee; -; KT338714; -; -. Goodyera $x$ tamnaensis C.S.Lee, S.H.Yeau, K.S.Lee, N.S.Lee; -; HM021598, HM021600; -; -. Kreodanthus simplex (C.Schweinf.) Garay; -; FJ473328*; FJ571281*; -. Ludisia discolor (Ker Gawl.) A.Rich.; -; KT344102*; KT385580*; MK451807*. Macodes dendrophila Schltr.; -; KT344103; -; -. Macodes petola (Blume) Lind1.; -; KT344104; -; -. Pristiglottis elongata (Blume) Cretz. \& J.J.Sm.; -; MT872160*; -; -. Pristiglottis spec.; -; -; KC467051; -. Pterostylis longifolia R.Br.; -; -; AJ409445*; AJ310062*. Pterostylis vittata Lindl.; -; AY134657*; -; -. Zeuxine affinis (Lindl.) Benth. ex Hook.f.; -; KT344114*; -; -. Zeuxine agyokuana Fukuy.; -; HM140997; -; -. Zeuxine odorata Fukuy.; -; KT344115; -; -. Zeuxine sp.; -; -; KT385581*; KT385664*. 